\title{
The Evaluation of Motivation and Sport Education Relationship
}

\begin{abstract}
Mustafa Bas
Correspondence: Mustafa Bas, Department of physical education and sport science of Karadeniz Technique University, Turkey.
\end{abstract}

Received: September 26, 2016

Accepted: October 12, 2016

Online Published: October 20, 2016

doi:10.11114/jets.v4i12.1895

URL: http://dx.doi.org/10.11114/jets.v4i12.1895

\begin{abstract}
Motivating and enjoyable experience are the factors that physical education teachers encounter with them. One of the educational models of sport is sport education that is a result of features reliable sport simulation that causes to positive motivational sport experiences. Participants were $120($ male $=100$, female $=20)$. The number of classes that selected for this study were six numbers such as soccer, basketball and football codes. There were 40 participants and 80 participants that were under two conditions as sport education condition and traditional condition, respectively. The participants selected the sport according to their favorites. Three questionnaires have answered for investigation intrinsic motivation, goal orientations and perceived under pre-test condition and post-test condition for evaluation. Significantly difference was indicated under traditional condition for the changes in perceived competence, task orientation and mastery climate in compare to the sport education condition. The traditional condition was related to the adaptive aspects of motivation decreasing for the students, but the sport education condition sustained the existed levels of motivation.
\end{abstract}

Keywords: motivation, education, sport, climate

\section{Introduction}

Sports can cause be the reason of human health and life happiness (Good and Brophy, 2000). Motivation is one of the key factors that effects on the student learning outcomes (Chen, 2001). Student motivation for physical education decreases as student advancement by school (Mowling et al., 2004). Intrinsic motivation and achievement motivation are two education and sport motivation series (Treasure and Roberts 2001; Zahariadis and Biddle 2004). The students special goals is a factor to learning motivation as positive or negative due to their. The students level of intrinsic motivation is one kind of individual motivation that is indicated as an important factor for positive motivated behavior determination in physical education and sport (Mitchell, 1996). Sport research (Pelletier et al., 1995) and physical education research (Ntoumanis, 2001) has showed the intrinsic motivation positive relation with the students feeling less bored, reporting greater self-effort and being more intent on future participation in physical activity field. Achievement goal theory has applied for student motivational responses explanation for learning enjoyment and effort (Nicholls, 1989). Positive motivational sport experiences providing for physical education due to the features of authentic sport simulation is one of the sport education model goals (Siedentop, 1994). Student motivation simultaneous social cognitive-based theories can help us to understand the reason of the curricular programs (Wallhead and Ntoumanis, 2004). The aim of this study is the effects of the sport education model on student motivation evaluation due to the secondary physical education and sport education and motivation relationship investigation. For comparison condition was used of traditional learning condition. Student motivation was evaluated in three subgroups as inner motivation, goal orientations and perceived motivational climate.

\section{Materials and Methods}

Participants were 120 (male $=100$, female $=20$ ). The classes that were selected to participant in this experiment were on the base of teacher and class availability for the football and basketball plays. 40 participants were under sport education condition and 80 participants were under traditional condition. The participants selected the sport according to their favorites. The participants answered three questions list series to evaluate goal orientations, inner motivation and perceived motivational climate under pre-test and post-test. IMI was applied to investigate the sport and physical education inner motivation (Ryan, 1982). For evaluation the goal orientations was used of the TEOSQ (Duda and Nicholls, 1992). The perceived motivational climate measurement was by the Perceived motivational climate at sport questionnaire (PMCSQ) (Walling et al., 1993). 
The participants that were under sport education condition integrated one double period (during 100 minutes) as one day per week during 10 weeks. Three to four weeks that included largely teacher-directed guidance for students' knowledge increasing about the plays such as ability and skill, drills and basic rules was the first phase of the study. Students performance as attention to their team roll and a team warm-up was the beginning typical education that this education included different skills and drills explanation and demonstration due to the teacher and then some student that were based on the controlled play activity and concluded with a improved play umpired by the teacher and another nominated student.

Under the traditional condition, the participants integrated one double period (100 minutes) per week for five weeks. For the traditional condition the education was similar together during the period of the study. Nearly 10 minutes aerobic warm-up was the typical beginning lesson of approximately 10 minutes that continued as static and dynamic stretches during 5 minutes and 30-40 minutes as skill development due to the sport specific drills organized using of the master education was done both individually and in small groups and 30-40 minutes encompassed game play finally that consisted of the two matched collected ability teams, that were again choiced by the master. The teacher did not guide about the class learning but the class was a normal physical education class. The data analysis was done by using of Cronach's alphas for determination their reliability. Research design was a non-equivalent control group design and a manipulation check was done at pre-test to check for any primary differences in motivation. Analyses of variance (ANOVAs) were performed for comparison the difference between two educational conditions on motivation with t-tests conducted to show the significant analysis. A comparison of the relationship between inner motivation, goal orientations and motivational climate was done by using of Pearson's product moment correlation coefficients.

\section{Results and Discussion}

Manipulation check was used for comparison the any initial differences under pre-test condition for motivation by using of a non-equivalent control group design. Significant differences did not indicated between the sport education and traditional conditions.

Table 1. Descriptive statistics for the measures of motivation

\begin{tabular}{|c|c|c|c|c|c|}
\hline \multirow{2}{*}{ Measure } & \multirow{2}{*}{ Condition } & \multicolumn{2}{|c|}{ Pre-test } & \multicolumn{2}{|c|}{ Post-test } \\
\hline & & Mean & SD & Mean & SD \\
\hline \multirow{2}{*}{ IMI } & Sport education & 16.12 & 3.45 & 17.40 & 2.80 \\
\hline & Traditional & $17.32 *$ & 3.01 & $16.60^{*}$ & 3.10 \\
\hline \multirow{2}{*}{ TEOSQ } & Sport education & 26.02 & 5.10 & 26.15 & 7.10 \\
\hline & Traditional & $26.98 *$ & 4.91 & $25.73^{*}$ & 6.25 \\
\hline \multirow{2}{*}{ PMCSQ } & Sport education & 32.21 & 5.94 & 33.43 & 6.64 \\
\hline & Traditional & $34.17 *$ & 5.08 & $33.22 *$ & 6.70 \\
\hline
\end{tabular}

$* \mathrm{P}<0.05$

According to the results for inner motivation was showed no significant difference between pre-test and post-test results as perceived competence for the sport education condition, but there was a significant decreasing on perceived competence scores for the traditional condition. Also, according to the pre- to post-test results on task orientation showed no significant difference under the sport education condition, but there was a significant difference under the traditional condition. This result demonstrated significantly orientation decreasing under the traditional condition from pre- to post-test. No significant change was reported in mastery climate under the sport education condition, but has shown a significant decreasing in scores under the traditional condition for mastery climate.

Alexander et al. (1993), who reported exultation and enjoyment increasing among the boys that participated at sport education class. The results supported the previous researches results about the teacher understanding of the sport education positive effect on student motivation in physical education (Alexander and Luckman, 2001; Grant, 1992). Alexander and Luckman (2001) asserted that a model training that can be included extended season, persisting groups, less direct teaching and more responsibility for students can cause the reason of the concept, aim and gladness for students in physical education. Hastie (1998) has demonstrated that the long season and insisting division of the sport education planning can raise student skill and tactical development. The aim of this study was the effect of the sport education model evaluation on the student motivation during secondary physical education season. There was significant difference between the sport education and traditional conditions on the base of perceived competence, task orientation and mastery climate changes by their measurements decreasing from pre-test to post-test under the traditional condition in compare to the sport education condition. Previous researches about the sport education model have demonstrated that this result can be connected to the student exultation, entanglement and participation (Wallhead and O'Sullivan, 2005). Wallhead and Ntoumanis (2004) found that sport education can cause to increase pleasure and understanding effort and a task-involving climate. The perceived motivational climate was more mastery oriented under the sport education condition than the traditional condition, that can be attached to the task orientation and positive 
motivation (Treasure and Roberts 2001). There were significant differences among the properties on perceived competence, task orientation and mastery climate make sense according to theoretical models, as the results of the motivational climate is likely to influence goal orientation and intrinsic motivation (Weinberg and Gould 2003). As a restricted factor for the design, can indicate the teacher effect. The teachers should be attended to the classes and their interaction and educational approach that have effects on the motivation. The teacher works and education factors were not measured in the study. In addition, did not measure or control the teacher purpose in the researches. Only the teachers aims that consider for the classes have effects on student outcomes that one the outcomes is motivation. The results proposed that maintaining high levels of inner motivation, task orientation and mastery climate of sport education condition can be more successful in compare to the traditional condition.

\section{References}

Alexander, K., \& Luckman, J. (2001). Australian teachers' perceptions and uses of the Sport Education curriculum model. European Physical Education Review, 7, 243-267. http://dx.doi.org/10.1177/1356336X010073002

Alexander, K., Taggart, A., \& Medland, A. (1993). Sport Education in physical education: Try before you buy. ACHPER National Journal, 40, 16-23.

Duda, J. L., \& Nicholls, J. (1992). Dimensions of achievement motivation in schoolwork and sport. Journal of Educational Psychology, 84, 1-10. http://dx.doi.org/10.1037/0022-0663.84.3.290

Good, T. L., \& Brophy, J. E. (2000). Looking into classrooms (5th ed.). New York: Longman. Chen, A. (2001). A theoretical conceptualization for motivation research in physical education: An integrated perspective. Quest, 2, $35-58$.

Grant, B. C. (1992). Integrating sport into the physical education curriculum in New Zealand secondary schools. Quest, 44, 304-316. http://dx.doi.org/10.1080/00336297.1992.10484057

Hastie, P. A. (1998). Skill and tactical development during a sport education season. Research Quarterly for Exercise and Sport, 69, 368-379. http://dx.doi.org/10.1080/02701367.1998.10607711

Mitchell, S.A. (1996). Relationships between perceived learning environment and intrinsic motivation in middle school physical education. Journal of Teaching in Physical Education, 15, 368-383. http://dx.doi.org/10.1123/jtpe.15.3.369

Mowling, C. M., Eiler, K. K., Brock, S. J., \& Rudisill, M. E. (2004). Student motivation in physical education. Journal of Physical Education, Recreation and Dance, 75(6), 40-51. http://dx.doi.org/10.1080/07303084.2004.10607256

Nicholls, J. G. (1989). The competitive ethos and democratic education. Cambridge, MA: Harvard University Press.

Ntoumanis, N. (2001). A self-determination approach to the understanding of motivation in physical education. British Journal of Education Psychology, 71, 225-242. http://dx.doi.org/10.1348/000709901158497

Pelletier, L. G., Fortier, M. S., Vallerand, R. J., Tuson, K. M., Briere, N. M., \& Blais, M. R. (1995). Toward a new measure of intrinsic motivation, extrinsic motivation, and amotivation in sports: The Sport Motivation Scale (SMS). Journal of Sport \& Exercise Psychology, 17, 35-53. http://dx.doi.org/10.1123/jsep.17.1.35

Ryan, R. M. (1982). Control and information in the intrapersonal sphere: An extrinsic of cognitive evaluation theory. Journal of Personality and Social Psychology, 43, 450-461. http://dx.doi.org/10.1037/0022-3514.43.3.450

Siedentop, D. (1994). Sport Education: Quality P.E. through positive sport experiences. Champaign, IL: Human Kinetics.

Treasure, D. C., \& Roberts, G. C. (2001). Students' perceptions of the motivational climate, achievement beliefs, and satisfaction in physical education. Research Quarterly for Exercise and Sport, 72, 165-175. http://dx.doi.org/10.1080/02701367.2001.10608946

Wallhead, T. L., \& Ntoumanis, N. (2004). Effects of a Sport Education intervention on students'motivational responses in physical education. Journal of Teaching in Physical Education, 23, 4-18. http://dx.doi.org/10.1123/jtpe.23.1.4

Wallhead, T., \& O'Sullivan, M. (2005). Sport Education: Physical education for the new millennium? Physical Education and Sport Pedagogy, 10(2), 181-210. http://dx.doi.org/10.1080/17408980500105098

Walling, M. D., Duda, J. L., \& Chi, L. (1993). The perceived motivational climate in sport questionnaire:Construct and predictive validity. Journal of Sport \& Exercise Psychology, 15, 172-183. http://dx.doi.org/10.1123/jsep.15.2.172

Weinberg, R. S., \& Gould, D. (2003). Foundations of sport and exercise psychology (3rd ed.). Champaign, IL: Human Kinetics.

Zahariadis, P. N., \& Biddle, J. H. (2004). Goal orientations and participation motives in physical education and sport: Their relationships in English schoolchildren. Athletic Insight, 12(1), 1-10.

\section{(cc) BY}

This work is licensed under a Creative Commons Attribution 3.0 License. 